\title{
Prognostic Value of Preoperative High-Sensitivity C-Reactive Protein/Albumin Ratio in Spinal Surgery
}

\author{
Spinal Cerrahide Preoperatif Yüksek Hassasiyetli \\ C-Reaktif Protein/Albumin Oranının Prognostik Değeri
}

\section{Özgün Araştrrma} Research Article

\section{Alındı̆̆ı tarih: 14.06 .2019 \\ Kabul tarihi: 26.08.2019 Online Yayın tarihi: 31.12.2019}

Arsal Acarbaş Muğla Sıtkı Koçman Üniversitesi Tıp Fakültesi Beyin Cerrahisi Bölümü,

Muğla - Türkiye arc1453@yahoo.com ORCiD: 0000-0002-8189-4071

Cite as: Acarbaş A. Prognostic value of preoperative high-sensitivity C-reactive protein/albumin ratio in spinal surgery. Tepecik Eğit. ve Araşt. Hast. Dergisi. 2019;29(3):253-8.

\section{Arsal Acarbaş $\bullet$}

\section{ABSTRACT}

Objective: The relation high-sensitivity C-reactive protein/albumin ratio (CAR) with perioperative adverse events have not been studied in patients undergoing spinal surgery (SS). This study aimed to evaluate the prognostic value of preoperative CAR on outcome of patients undergoing elective SS.

Method: A retrospective analysis of 811 consecutive patients, older than 18 years old and undergoing elective SS between October 2014 and January 2019 was performed. Demographic and clinical data were obtained from medical records. Routine preoperative laboratory tests including high-sensitivity C-reactive protein and albumin levels were recorded. The outcomes of interest were perioperative medical and surgical complications during hospitalization.

Results: The perioperative adverse event rate was 9.0\% (73 patients). The CAR was higher in in the individuals that experienced complicated in-hospital course than in those who did not $(30.2 \pm 27.5$ vs. 15.8 $24.5, p<0.001)$. Multivariate analysis showed that only age, higher CAR, and history of malignancy were significant and independent predictors of perioperative adverse events. The best cut-off value of the CAR was 5.25 , with $84.3 \%$ sensitivity and $85.2 \%$ specificity.

Conclusion: This is the first study to show an association between preoperative CAR and perioperative adverse events in patients undergoing SS.

Keywords: High-sensitivity C-reactive protein/albumin ratio, prognosis, spinal surgery

öz

Amaç: Spinal cerrahi geçiren hastalarda (SC) perioperatif yan etkilerle yüksek duyarlıklı C-reaktif protein/albumin oranı (CAR) arasındaki ilişki daha önce araştırılmamıştır. Bu çalışmada, preoperatif CAR'ın elektif SC geçiren hastalarındaki progniostik önemi araştırılmıştır.

Yöntem: Ekim 2014-Ocak 2019 tarihleri arasında 18 yaşından büyük ve elektif SC uygulanan 811 ardışık hastanın retrospektif analizi yapıldı. Demografik ve klinik veriler tıbbi kayıtlardan elde edildi. Yüksek duyarlıklı C-reaktif protein ve albumin seviyelerini içeren rutin ameliyat öncesi laboratuvar testleri kaydedildi. Hastanede yatış sırasındaki perioperatif tıbbi ve cerrahi komplikasyonlar incelendi.

Bulgular: Perioperatif advers olay oranı \%9,0 idi (73 hasta). CAR, hastane içi verilerde komplike olan hastalarda

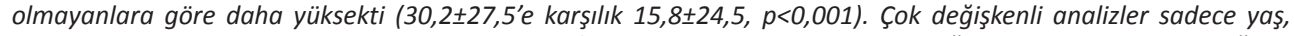
yüksek CAR ve malignite öyküsünün perioperatif advers olayların önemli ve bağımsız belirleyicileri olduğunu göstermiştir. CAR'ın en iyi kesim değeri \%84,3 duyarlıık ve \%85,2 özgüllük ile 5,25 olmuştur.

Sonuç: Bu, SC geçiren hastalarda preoperatif CAR ve perioperatif advers olaylar arasındaki ilişkiyi gösteren ilk çalış̧madır.

Anahtar kelimeler: Prognoz, spinal cerrahi, yüksek duyalıklı C-reaktif protein/albümin oranı

(C) Telif hakkı T.C. Sağılık Bakanlığı İzmir Tepecik Eğit. ve Araşt. Hastanesi. Logos Tıp Yayıncııık tarafindan yayınlanmaktadır. Bu dergide yayınlanan bütün makaleler Creative Commons Attf-GayriTicari 4.0 Uluslararası Lisansı ile lisanslanmıştır.

(c) Copyright Association of Publication of the T.C. Ministry of Health izmir Tepecik Education and Research Hospital. This journal published by Logos Medical Publishing. Licenced by Creative Commons Attribution-NonCommercial 4.0 International (CC BY-NC 4.0) 


\section{INTRODUCTION}

More than 234 million surgical procedures are performed every year in the world according to data from the World Health Organization ${ }^{(1)}$. The aging of the population and advances in surgical techniques have increased the rates of spinal surgery (SS) in recent years ${ }^{(2)}$. Therefore, it is important to predict perioperative adverse events which are associated with increased morbidity, mortality, and prolonged length of stay in patients undergoing SS ${ }^{(3-5)}$. Although several clinical variables have been studied as preoperative predictors of outcomes ${ }^{(6-8)}$ there are little data about the significance of preoperative biomarkers on postoperative outcome following SS.

Serum albumin and high sensitivity C-reactive protein (hs-CRP) are one of the most prevalently monitored biomarkers in clinical practice. Pre- or postoperative hypoalbuminemia and higher levels of CRP has been recognized as a strong predictor of a worse prognosis but the data about the impact of preoperative hs-CRP on outcome, is much more limited in patients undergoing SS ${ }^{(9-12)}$.

Previous studies have shown that the integration of hs-CRP and albumin, hs-CRP to albumin ratio (CAR), has more value than either alone with regards to making predictions of the prognosis in various conditions ${ }^{(13)}$. However, this marker has never been employed in SS patients. Therefore, the objective of this study was to test the hypothesis that an elevated CAR at admission increases the risk of perioperative complications following SS.

\section{MATERIAL and METHODS}

\section{Study design and selection of patients}

The study was a retrospective, observational, and single-center study, conducted at the Mugla Sitki Kocman University Hospital from October 2014 and January 2019. All consecutive patients with $\geq 18$ years of age, undergoing elective SS (laminectomy, arthrodesis, discectomy, and/or laminectomy in any region of the spine) were recruited. Demographic, clinical, laboratory data and surgery-related information were collected from electronic medical records. Complete blood count and routine biochemical analyses such as creatinine, hemoglobin, electrolytes, and hs-CRP were also included. The hs-CRP level was measured using a turbidimetric immunoassay (Wako Chemicals, Osaka, Japan) on a Hitachi 7600 chemistry analyzer (Hitachi, Tokyo, Japan). The detection limit for hs-CRP was $0.1 \mathrm{mg} / \mathrm{L}$; intra- and inter-assay coefficients of variations were $5.2 \%$, and $6.4 \%$, respectively. The CAR was calculated by dividing the serum hs-CRP level (mg/L) by the serum albumin level $(\mathrm{g} / \mathrm{L})$.

Patients requiring emergency surgery were excluded. Patients with incomplete medical record; no hs-CRP or albumin measurement preoperatively; and patients with follow-up loss were also excluded.

This study was approved by the institutional regional ethics committee.

\section{Study outcomes}

The outcomes of interest were perioperative adverse events during hospitalization. These adverse events were defined as surgical site infection, bacteremia, acute kidney injury, pneumonia, sepsis, venous thromboembolism, cardiac arrest, stroke, cardiovascular complications (arrhythmias requiring treatment, acute heart failure, acute coronary syndrome), and in-hospital mortality. Acute coronary syndrome was defined as previously described ${ }^{(14)}$.

\section{Statistical analysis}

Data were analyzed using SPSS for Windows (version 15; SPSS Inc, Chicago, IL). The continuous variables were expressed as meantstandart deviation and were compared between groups (patients with and without perioperative adverse events) by 2-tailed Student $\mathrm{t}$ test. Univariate and multivariate logistic regression analyses were applied to determine crude 
and adjusted odds ratios (ORs) and 95\% confidence intervals (Cls) for the relationship between preoperative variables and perioperative adverse events. In order to determine the optimal cut-off value for the CAR, a receiver operative characteristics (ROC) curve analysis was performed using the likelihood of perioperative complications after SS.

\section{RESULTS}

A total of 1586 patients older than 18 years were underwent SS during the study period. Of those, 655 patients were excluded because they had incomplete medical record or no hs-CRP or albumin measurement preoperatively; 120 were excluded because they had emergent surgery. The remaining 811 patients (mean age 69.4 $\pm 7.6,52 \%$ male) were finally included in this study.

Of the 811 patients, 73 (9\%) had experienced perioperative complications. Baseline characteristics of patients with or without perioperative adverse events are presented in (Table 1). Hypertension was the most common comorbidity in both groups. Prevelance of heart failure, coronary artery disease,

Table 1. Baseline characteristics of patients with and without perioperative adverse events.

\begin{tabular}{lccc}
\hline & $\begin{array}{c}\text { No } \\
\text { adverse } \\
\text { event } \\
\text { (n=738) }\end{array}$ & $\begin{array}{c}\text { Adverse } \\
\text { event } \\
(\mathbf{n}=73)\end{array}$ & P value \\
\hline Male & $385(52.2)$ & $37(50.7)$ & 0.141 \\
Age & $67.4 \pm 7.5$ & $72.7 \pm 8.9$ & 0.004 \\
Medical History & & & \\
Hypertension & $352(47.7)$ & $35(47.9)$ & 0.62 \\
Hyperlipidemia & $286(38.7)$ & $25(34.2)$ & 0.67 \\
Diabetes mellitus & $201(27.2)$ & $24(32.8)$ & 0.09 \\
Atrial fibrillation & $103(13.9)$ & $18(24.6)$ & 0.02 \\
Chronic obstructive pulmonary disease & $105(14.2)$ & $14(19.2)$ & 0.13 \\
Malignancy & $86(11.6)$ & $15(20.5)$ & $<0.001$ \\
Coronary artery disease & $189(25.6)$ & $18(24.6)$ & 0.72 \\
Heart failure & $105(14.2)$ & $11(15.1)$ & 0.48 \\
Laboratory results & & & \\
Hemoglobin (g/dL) & $12.2 \pm 1.52$ & $12.5 \pm 1.63$ & 0.42 \\
Albumin (g/dL) & $3.6 \pm 0.61$ & $3.1 \pm 0.40$ & $<0.001$ \\
Creatinine (mg/dL) & $1.1 \pm 0.38$ & $1.1 \pm 0.41$ & 0.54 \\
hs-CRP (mg/dL) & $5.2 \pm 6.3$ & $8.4 \pm 7.4$ & $<0.001$ \\
hs-CRP/albumin ratio & $15.8 \pm 24.5$ & $30.2 \pm 27.5$ & $<0.001$ \\
& & & \\
\hline
\end{tabular}

Values are given as mean $\pm S D$ or number (percentage). hs-CRP, high-sensitivity $C$-reactive protein hypertension, hyperlipidemia, and chronic obstructive pulmonary disease were similar between two groups. While there was an elevated risk of perioperative complications in diabetics, it did not reach statistical significance. Patients with complicated in-hospital course were older, and were more likely to have atrial fibrillation and history of malignancy. Patients who had perioperative complications had higher values of hs-CRP and but lower levels of albumin before SS. The CAR was higher in patients with perioperative complications than in patients without complications.

Perioperative medical and surgical adverse events are summarized in (Table 2). The most common medical complications were acute coronary syndrome, prolonged mechanical ventilation and acute renal failure and the most common surgical complication was surgical wound infection.

In the univariate analyses, older age, presence of atrial fibrillation, history of cancer, and, CAR showed statistically significant associations with perioperati-

Table 2. Perioperative complications.

\begin{tabular}{lc}
\hline Type of Complication & Number of Patients \\
\hline Medical complications & 43 \\
Acute coronary syndrome & 7 \\
Prolonged mechanical ventilation & 7 \\
Acute renal failure & 7 \\
Acute heart failure & 6 \\
Severe arrhythmia & 5 \\
Pulmonary embolism & 3 \\
Sepsis or septic shock & 3 \\
Nonfatal cardiac arrest & 3 \\
Arterial thromboembolism & 2 \\
Surgical complications & 30 \\
Wound infection & 25 \\
Minor bleeding & 4 \\
Major bleeding & 1 \\
\hline
\end{tabular}

Table 3. Multivariate analysis for the prediction of perioperative adverse events.

\begin{tabular}{lccc}
\hline & OR & $95 \%$ Cl & P \\
\hline Age (per 1 y) & 2.13 & $1.14-4.38$ & $<0.01$ \\
Atrial fibrillation (presence vs absent) & 1.02 & $0.43-3.11$ & 0.54 \\
Malignancy (presence vs absent) & 3.11 & $1.15-5.32$ & $<0.01$ \\
hs-CRP/albumin ratio $>$ 5.25 & 2.01 & $1.02-4.23$ & $<0.01$ \\
\hline
\end{tabular}


ve adverse events. Multivariate analysis showed that only age, CAR $>5.25$, history of malignancy were significant and independent predictors of perioperative adverse events (Table 3 ). CAR was associated with higher rates of perioperative edverse events after adjustment for age, and presence of malignancy (OR: $2.01,95 \% \mathrm{Cl}: 1.02-4.23)$. The CAR was associated with both medical (OR: $2.54,95 \% \mathrm{Cl}: 1.13-5.33$ ) and surgical adverse events (OR: $1.74,95 \% \mathrm{Cl}$ : 1.083.54). The best cut-off value of the CAR for parioperative adverse events (medical and surgical) was 5.25 , with $84.3 \%$ sensitivity and $85.2 \%$ specificity. The area under the curve of the CAR was 0.628 (95\% $\mathrm{Cl}, 0.577$ to 0.763 ) (Figure 1).

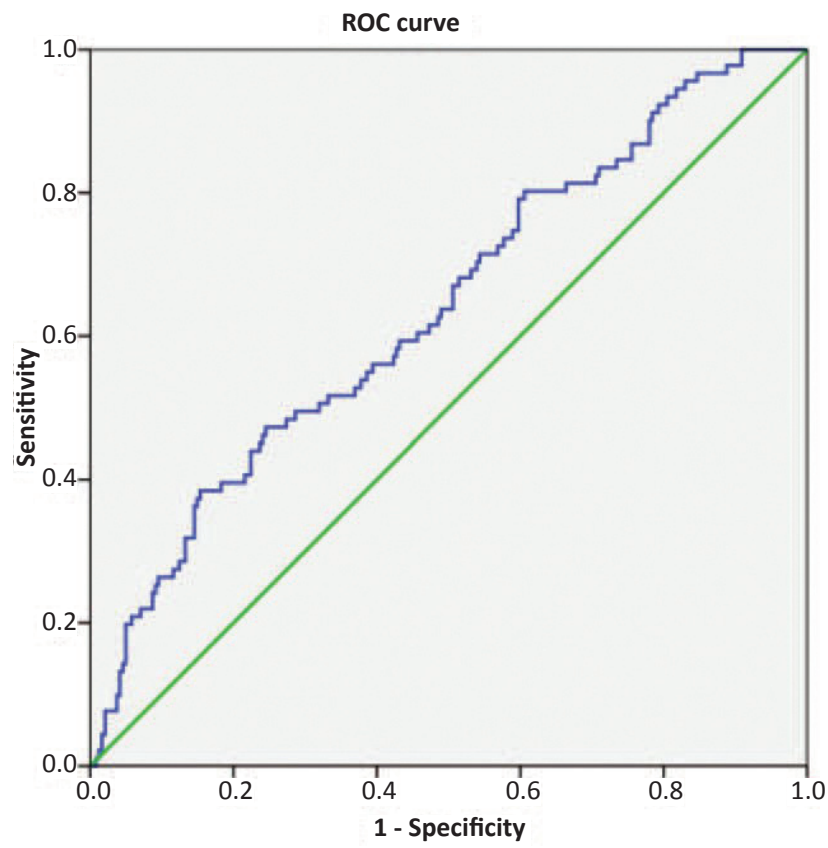

Figure 1. Receiver-operating characteristic curve. Area under curve $0.628(95 \% \mathrm{Cl}, 0.577$ to 0.763$)$.

\section{DISCUSSION}

In this study, the associations between selected clinical and laboratory markers and perioperative complications were examined after SS. In our study, $9 \%$ of the patients experienced perioperative complications and only the CAR was an independent prognostic factor among the biomarkers. This result supports our expectation that the CAR is a novel prognostic indicator to predict perioperative adverse events in SS patients. To the best of our knowledge, this is the first report to investigate the prognostic value of the CAR in patients undergoing SS.

Operative injury causes acute phase responses in the body and this response has been examined by several biomarkers such as cortisol, interleukin-6, white cell count, and CRP ${ }^{(15)}$. Other biomarkers of systemic inflammation such as neutrophil to lymphocyte ratio, platelet to lymphocyte ratio, and lymphocyte to monocyte ratio have also been reported to be effective predictors of outcomes in various surgical procedures ${ }^{(16-18)}$. The CAR is a novel systemic inflammation biomarker and a high ratio of CAR indicates higher residual inflammation superimposed with malnutrition status ${ }^{(13)}$. The CAR has been recently shown to be a significant prognostic factor in several types of surgeries ${ }^{(19,20)}$. However, up to now, the association between the preoperative CAR and the perioperative complications has not been studied in SS patients. Although hs-CRP is known to have better sensitivity than CRP for inflammation, there are only a few studies evaluating its association between risk of vertebral fractures or its prognostic value in patients undergoing SS ${ }^{(21-23)}$. Eriksson and colleagues investigated associations between hs-CRP and fracture risk in a large prospective population-based cohort of elderly Swedish men The authors showed that at elderly men with high hs-CRP had an increased risk of fractures, which were mainly vertebral fractures ${ }^{(21)}$. Rathod et al. ${ }^{(22)}$ investigated whether hs-CRP can be an objective tool to predict postoperative recovery assessed by modified Oswestry Back Disability Score in patients undergoing lumbar discectomy. They demonstrated a significant positive correlation between preoperative hs-CRP level and postoperative scores. Sugimori and colleagues measured the serum concentration of hs-CRP in 48 patients with lumbar disc herniation and in 53 normal controls ${ }^{(23)}$. They sought to determine the differences in hs-CRP concentrations between patient and control groups and they also 
aimed to find the prognoostic value of hs-CRP in patients undergoing lumbar disc surgery. The results of this study revealed that the concentration of hs-CRP was significantly higher in the patients than in the controls. Moreover, patients with a higher concentration of hs-CRP before operation showed a poorer recovery after surgery ${ }^{(23)}$.

In the current study, we aimed to investigate whether the preoperative CAR was independently associated with the development perioperative adverse event and we found that the CAR was an independent and significant risk factor perioperative complications in SS. The mechanism linking predictive value of CAR to perioperative complications is unclear, but it has been speculated that high concentration of serum hs-CRP might indicate a systemic inflammatory response and hypoalbuminemia might indicate malnutrition. Chronic inflammation and malnutrition might be a predictor of complications after operation.

\section{Limitations}

There are a few limitations in the present study. First, hs-CRP is a non-specific marker of inflammation, and it is possible that the presence of other systemic diseases could influence hs-CRP concentrations. Second, this study used preoperative hs-CRP and albumin levels and their postoperative levels of was not measured. Third, the present study is a retrospective observational study conducted in a single institution, which makes it prone to selection bias. Fourth, although our results revealed that the CAR was associated with both medical and surgical adverse events, detailed statistical analyses could not be performed in these groups as the number of the some complications were low and Chi-square tests were not reliable for small numbers (for a total less than 40 and an expected number in a row less than 5).

\section{CONCLUSIONS}

This is the first study to use preoperative CAR to predict of SS patients. The results of the current study suggested that the preoperative CAR is a prognostic marker to predict adverse events after elective SS in adults. Further prospective studies are warranted to validate the CAR as a novel prognostic marker for patients undergoing SS.

Ethics Committee Approval: T. C. Muğla Sıtkı Koçman University Rectorship Clinical Research Ethics Committee approval was obtained (02.05.2019/08/IX).

\section{Conflict of Interest: None.}

Funding: None.

Informed Consent: It was not taken because it was retrospective.

Etik Kurul Onayı: T.C. Muğla Sıtkı Koçman Üniversitesi Rektörlüğü Klinik Araştırmalar Etik Kurulu onayı alınmıştır (02.05.2019/08/IX).

Çıkar Çatışması: Yoktur.

Finansal Destek: Yoktur.

Hasta Onamı: Retrospektif olduğu için alınmadı.

\section{REFERENCES}

1. Weiser TG, Regenbogen $S E$, Thompson $K D$, Haynes $A B$, Lipsitz SR, Berry WR, et al. An estimation of the global volume of surgery: a modelling strategy based on available data. Lancet. 2008;372(9633):139-44. [CrossRef]

2. Kobayashi K, Ando K, Nishida $\mathrm{Y}$, Ishiguro N, Imagama S. Epidemiological trends in spine surgery over 10 years in a multicenter database. Eur Spine J. 2018;27(8):1698-703. [CrossRef]

3. Visser A, Geboers B, Gouma DJ, Goslings JC, Ubbink DT. Predictors of surgical complications: A systematic review. Surgery. 2015;158(1):58-65. [CrossRef]

4. Tetreault L, Ibrahim A, Côté P, Singh A, Fehlings MG. A systematic review of clinical and surgical predictors of complications following surgery for degenerative cervical myelopathy. J Neurosurg Spine. 2016;24(1):77-99. [CrossRef]

5. Pereira BJ, de Holanda CV, Ribeiro CA, Holanda LF, Cabral CD, et al. Spinal surgery for degenerative lumbar spine disease: Predictors of outcome. Clin Neurol Neurosurg. 2016;140:1-5. [CrossRef]

6. Proietti L, Scaramuzzo L, Schiro' GR, Sessa S, Logroscino CA. Complications in lumbar spine surgery: A retrospective analysis. Indian J Orthop. 2013;47(4):340-5. [CrossRef]

7. McLynn RP, Ondeck NT, Cui JJ, Swanson DR, Shultz BN, Bovonratwet $\mathrm{P}$,et al. The Rothman Index as a predictor of 
postdischarge adverse events after elective spine surgery. Spine J. 2018;18(7):1149-56. [CrossRef]

8. Lakomkin N, Goz V, Cheng JS, Brodke DS, Spiker WR. The utility of preoperative laboratories in predicting postoperative complications following posterolateral lumbar fusion. The Spine Journal. 2018;18:993-7. [CrossRef]

9. Nazemi AK, Gowd AK, Carmouche JJ, Kates SL, Albert TJ, Behrend CJ. Prevention and Management of Postoperative Delirium in Elderly Patients Following Elective Spinal Surgery. Clin Spine Surg. 2017;30(3):112-9. [CrossRef]

10. Liu JM, Deng HL, Chen XY, Zhou Y, Yang D, Duan MS, et al. Risk Factors for Surgical Site Infection After Posterior Lumbar Spinal Surgery. Spine (Phila Pa 1976). 2018;43(10):732-7. [CrossRef]

11. Mok JM, Pekmezci M, Piper SL, Boyd E, Berven SH, Burch S, et al.Use of C-reactive protein after spinal surgery: comparison with erythrocyte sedimentation rate as predictor of early postoperative infectious complications. Spine (Phila Pa 1976). 2008;33(4):415-21. [CrossRef]

12. Rathod TN, Chandanwale A, Ladkat KM, Chavan S, Chavan A, Bhosale PB. High sensitive C-reactive protein-Effective tool in determining postoperative recovery in lumbar disc disease. Indian J Orthop. 2014;48(4):354-9. [CrossRef]

13. Oh J, Kim SH, Park KN, Oh SH, Kim YM, Kim HJ, et al.Highsensitivity C-reactive protein/albumin ratio as a predictor of in-hospital mortality in older adults admitted to the emergency department. Clin Exp Emerg Med. 2017;4(1):19-24. [CrossRef]

14. Thygesen K, Alpert JS, Jaffe AS, Chaitman BR, Bax JJ, Morrow DA, et al; ESC Scientific Document Group. Fourth universal definition of myocardial infarction (2018). Eur Heart J. 2019;40(3):237-69.

15. Watt DG, Horgan PG, McMillan DC. Routine clinical markers of the magnitude of the systemic inflammatory response after elective operation: a systematic review. Surgery. 2015;157(2):362-80. [CrossRef]
16. Leithead JA, Rajoriya N, Gunson BK, Ferguson JW. Neutrophilto-lymphocyte ratio predicts mortality in patients listed for liver transplantation. Liver Int. 2015;35(2):502-9. [CrossRef]

17. Lee BM, Rodriguez A, Mena G, Gottumukkala V, Mehran RJ, Rice DC, et al. Platelet-to-Lymphocyte Ratio and Use of NSAIDs During the Perioperative Period as Prognostic Indicators in Patients With NSCLC Undergoing Surgery. Cancer Control. 2016;23(3):284-94. [CrossRef]

18. Lieto E, Galizia G, Auricchio A, Cardella F, Mabilia A, Basile N, et al. Preoperative Neutrophil to Lymphocyte Ratio and Lymphocyte to Monocyte Ratio are Prognostic Factors in Gastric Cancers Undergoing Surgery. J Gastrointest Surg. 2017;21(11):1764-74. [CrossRef]

19. Oh TK, Choi YR, Cho JY, Yoon YS, Han HS, Park IS, et al.The High-Sensitivity C-Reactive Protein/Albumin Ratio Predicts Long-Term Oncologic Outcomes after Curative Resection for Hepatocellular Carcinoma. Clin Med. 2018;7(6):pii:E139. [CrossRef]

20. Xu H, Hu L, Wei X, Niu J, Gao Y, He J, et al. The Predictive Value of Preoperative High-Sensitive C-Reactive Protein/ Albumin Ratio in Systemic Inflammatory Response Syndrome After Percutaneous Nephrolithotomy. J Endourol. 2019;33(1):1-8. [CrossRef]

21. Eriksson AL, Movérare-Skrtic S, Ljunggren Ö, Karlsson $M$, Mellström D, Ohlsson C. High-sensitivity CRP is an independent risk factor for all fractures and vertebral fractures in elderly men: the MrOS Sweden study. J Bone Miner Res. 2014;29(2):418-23. [CrossRef]

22. Rathod TN, Chandanwale A, Ladkat KM, Chavan S, Chavan A, Bhosale PB. High sensitive C-reactive protein-Effective tool in determining postoperative recovery in lumbar disc disease. Indian J Orthop. 2014;48(4):354-9. [CrossRef]

23. Sugimori K, Kawaguchi $Y$, Morita M, Kitajima I, Kimura T. High-sensitivity analysis of serum C-reactive protein in young patients with lumbar disc herniation. Bone Joint Surg Br. 2003;85(8):1151-4. [CrossRef] 